\title{
Multiplex qPCR for reliable detection and differentiation of Burkholderia mallei and Burkholderia pseudomallei
}

\author{
Ingmar Janse ${ }^{1 *}$, Raditijo A Hamidjaja ${ }^{1}$, Amber CA Hendriks $^{2}$ and Bart J van Rotterdam
}

\begin{abstract}
Background: Burkholderia mallei and B. pseudomallei are two closely related species of highly virulent bacteria that can be difficult to detect. Pathogenic Burkholderia are endemic in many regions worldwide and cases of infection, sometimes brought by travelers from unsuspected regions, also occur elsewhere. Rapid, sensitive methods for identification of B. mallei and B. pseudomallei are urgently needed in the interests of patient treatment and epidemiological surveillance.
\end{abstract}

Methods: Signature sequences for sensitive, specific detection of pathogenic Burkholderia based on published genomes were identified and a QPCR assay was designed and validated.

Results: A single-reaction quadruplex qPCR assay for the detection of pathogenic Burkholderia, which includes a marker for internal control of DNA extraction and amplification, was developed. The assay permits differentiation of B. mallei and B. pseudomallei strains, and probit analysis showed a very low detection limit. Use of a multicopy signature sequence permits detection of less than 1 genome equivalent per reaction.

Conclusions: The new assay permits rapid detection of pathogenic Burkholderia and combines enhanced sensitivity, species differentiation, and inclusion of an internal control for both DNA extraction and PCR amplification.

Keywords: Burkholderia mallei, Burkholderia pseudomallei, Glanders, Melioidosis, Detection, qPCR, Sensitive detection, Internal amplification control

\section{Background}

The ubiquitous Proteobacterial genus Burkholderia includes several animal and plant pathogens. Two closely related Burkholderia species cause severe, potentially fatal disease in humans. Burkholderia mallei is an obligate mammalian pathogen that causes glanders, a disease that is found in much of the world apart from North America, Europe and Australia. The disease mainly affects solipeds, but transmission to humans is possible through direct contact with animals and aerosols. Naturally infected human cases are reported only sporadically, but the causative agent is highly pathogenic under laboratory conditions and there have been several reports of laboratory-acquired infections [1].

\footnotetext{
* Correspondence: ingmar.janse@rivm.nl

'Laboratory for Zoonoses and Environmental Microbiology, National Institute for Public Health and the Environment (RIVM), Anthonie van

Leeuwenhoeklaan 9, Bilthoven, MA 3721, The Netherlands

Full list of author information is available at the end of the article
}

Burkholderia pseudomallei is present in the environment and is a facultative pathogen that causes melioidosis, a glanders-like disease. It is a disease of humans and animals in all tropical and sub-tropical regions, but particularly South and Southeast Asia and northern Australia. Cases, included those brought by travelers, also occur outside endemic regions [2,3]. Glanders and melioidosis cause diagnostic problems in endemic regions, and even more so when imported into non-endemic areas due to a lack of awareness of these diseases there.

The variety of clinical manifestations means that the diagnosis of melioidosis or glanders cannot be based on symptomatic evidence alone and currently requires cultivation of the causative agent. This is a time-consuming process, and even more time is needed to confirm the species involved by means of biochemical tests. Moreover, 
misidentification due to the use of rapid biochemical methods has been reported $[4,5]$.

Timely recognition of B. mallei and B. pseudomallei is vital for appropriate therapy, since both pathogens cause rapidly progressive diseases and are resistant to several antibiotics. These features, together with the relative ease with which these pathogens can be obtained and transmitted, the difficulties experienced in diagnosing the resultant diseases, and the fact that no effective protection through vaccination exists, have put them in the highest risk category of biothreat agents (classified as 'Tier 1' under the revised US select agents regulations, http://www.selectagents.gov). It is thus vital to have fast, sensitive methods for the identification of $B$. mallei and B. pseudomallei, both for patient treatment and for epidemiological surveillance and forensic investigation in the event of their deliberate release.

Several molecular tests using different detection platforms have been described for this purpose [6,7]. A realtime single-reaction assay for detection would however permit faster detection with less effort. Such assays for the detection and differentiation of $B$. mallei and B. pseudomallei, based on duplex hydrolysis probes for allelic discrimination, were recently described $[6,8]$. These assays did not include internal controls for DNA extraction and PCR amplification, however. Moreover, reliance on one signature sequence for detection of pathogenic Burkholderia may not be sufficiently specific, since B. pseudomallei and B. mallei display considerable genomic plasticity $[9,10]$ and emerging novel strains will continue to challenge the coverage and sensitivity of these assays.

We have developed a single-reaction quadruplex qPCR assay for rapid, reliable detection of pathogenic Burkholderia. The assay combines enhanced sensitivity based on use of a specific multicopy sequence shared by both species, robust differentiation based on use of two different species-specific signature sequences, and enhanced reliability due to the incorporation of a marker that serves as internal control for DNA extraction and PCR amplification.

\section{Methods}

\section{Design of primers and probes for multiplex hydrolysis probe assay}

Both completed and unfinished genomes from B. mallei (10) and B. pseudomallei (29) available from public databases were analyzed by using the software package Kodon for management and analysis of sequences (www.applied-maths.com) and the insignia web tool (http://insignia.cbcb.umd.edu). Several potential signature sequences were identified for these organisms. The transposase ISBma2 was present in about $40-50$ copies in B. mallei and about 5 copies in B. pseudomallei. Although this transposase has homologues in other organisms, a region of approximately 150 bp could be identified, which is present exclusively in $B$. mallei and B. pseudomallei, and not in B. oklahomensis. In addition, several unique signature sequences for differentiation of B. mallei and B. pseudomallei were identified. Out of these, the longest unique sequences were selected for primer and probe design. Both signature sequences corresponded to hypothetical proteins. The B. pseudomallei signature sequence psu corresponded to locus BPSS1387 in the published genome of strain K96243 (Genebank accession number BX571966). This gene codes for a putative acetyltransferase, which is part of the type III secretion system-associated gene cluster. B. mallei signature sequence mau corresponded to locus BMA2524.1 in the published genome of strain ATCC 23344 (Genebank accession number CP000010). This gene codes for a phage integrase family protein.

The Cry1 gene of Bacillus thuringiensis was used as a signature sequences for the detection of this organism. Addition of these highly refractory spores to the assays served as internal control for DNA isolation and amplification (see also $[11,12]$ ). The software package Visual OMP (www.DNAsoftware.com) was used to design a 4-target real-time PCR, as was described before [12]. An initial design yielded an unexpectedly high $\mathrm{Cq}$ for the multicopy sequence for two B. pseudomallei isolates (NCTC 4845 and NCTC 12939 T). Sequence analysis revealed a variation at one position of the probe annealing site, and a degeneracy was introduced to cover all strain variants (Table 1).

\section{PCR and real-time qPCR}

Oligonucleotides were synthesized by Biolegio (Biolegio, Nijmegen, the Netherlands).

All qPCR reactions were carried out in a final volume of $20 \mu$ containing iQ Multiplex Powermix (Bio-Rad, Veenendaal, the Netherlands), $200 \mathrm{nM}$ of each primer and 100-300 nM hydrolysis probes and $3 \mu \mathrm{l}$ of DNA template. Probe concentrations had been optimized to yield minimal spectral overlap between fluorescence level of the reporter dyes for each target in a multiplex assay and were 100, 200, 300 and $300 \mathrm{nM}$ for FAM, JOE, CFR590 and Cy5 labeled probes respectively. The thermal cycling conditions were as follows: first enzyme activation at $95^{\circ} \mathrm{C}$ for $5 \mathrm{~min}$, followed by amplification and detection by 45 thermocycles at $95^{\circ} \mathrm{C}$ for $5 \mathrm{sec}$ and $60^{\circ} \mathrm{C}$ for $35 \mathrm{sec}$. Each real-time qPCR experiment included a negative (no template) control. Measurements were carried out on a LightCycler 480 (Roche, Almere, the Netherlands). Analyses were performed on the instruments software: LightCycler 480 Software release 1.5.0. SP3 and Cq values were calculated using the second derivative method. Color compensation was carried out according to the manufacturers' guidelines. 
Table 1 Primers and probes for multiplex qPCR

\begin{tabular}{|c|c|c|c|c|}
\hline Organism & Target & Oligo function & Oligo name & Sequence $5^{\prime}-3^{\prime}{ }^{a}$ \\
\hline $\begin{array}{l}\text { B. pseudomallei + } \\
\text { B. mallei }\end{array}$ & $\begin{array}{l}\text { ISBma2 } \\
\text { transposase }\end{array}$ & $\begin{array}{l}\text { primer } \\
\text { primer } \\
\text { probe }\end{array}$ & $\begin{array}{l}\text { Bumcpri_f } \\
\text { Bumcpri_r } \\
\text { Tapro_Bumc }\end{array}$ & $\begin{array}{l}\text { GCGGAAGCGGAAAAAGGG } \\
\text { GCGGGTAGTCGAAGCTG } \\
\text { FAM-TCRCCAGACGCAGCAGCAT-BHQ1 }\end{array}$ \\
\hline B. pseudomallei & $\begin{array}{l}\text { Hypothetical } \\
\text { protein }\end{array}$ & $\begin{array}{l}\text { primer } \\
\text { primer } \\
\text { probe }\end{array}$ & $\begin{array}{l}\text { psupri_f } \\
\text { psupri_r } \\
\text { Tapro_psu }\end{array}$ & $\begin{array}{l}\text { GCGCGATCCGTCGAG } \\
\text { AGCCGCTACGACGATTATG } \\
\text { JOE-CCGCGACAATACGACCATCC-BHQ1 }\end{array}$ \\
\hline B. mallei & $\begin{array}{l}\text { Hypothetical } \\
\text { protein }\end{array}$ & $\begin{array}{l}\text { primer } \\
\text { primer } \\
\text { probe }\end{array}$ & $\begin{array}{l}\text { maupri3_f } \\
\text { maupri3_r } \\
\text { Tqpro2_mau }\end{array}$ & $\begin{array}{l}\text { GGCGAAAGAACGCGAAC } \\
\text { GCGTTCCACGATCAACTCT } \\
\text { CF590-CATCCCGCACCGTCCG-BHQ2 }\end{array}$ \\
\hline B. thuringiensis & $\begin{array}{l}\text { Crystal protein } \\
\text { gene }\end{array}$ & $\begin{array}{l}\text { primer } \\
\text { primer } \\
\text { probe }\end{array}$ & $\begin{array}{l}\text { Btpri_f } \\
\text { Btpri_r } \\
\text { Tqpro_Bt }\end{array}$ & $\begin{array}{l}\text { GCAACTATGAGTAGTGGGAGTAATTAC } \\
\text { TTCATTGCCTGAATTGAAGACATGAG } \\
\text { Cy5-ACGTAAATACACT-BHQ2-TGATCCATTTGAAAAG-P }\end{array}$ \\
\hline
\end{tabular}

${ }^{\mathrm{a}}$ CFR590= CalFluor Red 590, BHQ= Black Hole quencher, $\mathrm{P}=$ phosporylation.

\section{Bacterial isolates and genomic DNA preparation}

The detection limits and specificities of the assays were evaluated using genomic materials from the bacterial strains and other sources displayed in Table 2. More details about the source and handling of the materials can be found in [12]. Lysates from the clinical isolates designated $\mathrm{BD}$ (Table 2) were prepared by boiling colonies cultivated on blood agar plates in water for $30 \mathrm{~min}$. Autopsy materials were obtained from a melioidosis patient. A QIAamp DNA Mini kit (Qiagen, Crawley, UK) was used to extract DNA from liver, spleen, lung and prostate tissue samples. Spore suspensions of B. thuringiensis strain ATCC 29730 (var. galleriae Heimpel) that were used as internal controls, were obtained from Raven Biological Laboratories (Omaha, Nebraska, USA). These washed spores were counted by microscopy and then aliquotted and stored at $4^{\circ} \mathrm{C}$. The amount of spores that needs to be added to samples to obtain suitable $\mathrm{Cq}$ values for this internal control must be determined empirically for each stock spore suspension. Ten-fold serial dilutions were made from the spore stock and DNA was extracted from $50 \mu \mathrm{l}$ portions of each dilution by using the Nuclisens Magnetic Extraction Reagents (bioMérieux). The developed real-time qPCR assays were used to determine the amount of spores required for a $\mathrm{Cq}$ value between 32 and 35.

\section{Limit of detection, efficiency, repeatability and internal control dynamic range}

Characterization of $\mathrm{qPCR}$ performance was guided by the MIQE guidelines [13]. Validations were carried out using genomic DNA that was purified from culture lysates. Detection limits (LOD) for genomic DNA were determined by using purified DNA from cultures of B.mallei strain NCTC 10229 and B. pseudomallei strain NCTC 10276. The concentration of purified genomic DNA was measured by using the Quant-iT ${ }^{\mathrm{Tx}}$ PicoGreen dsDNA detection kit (Invitrogen) and a Fluoroskan Ascent Microplate fluorometer (Thermo Scientific). Serial dilutions of genomic DNA were used to calculate LODs from the proportion of positive qPCRs at each dilution. Four replicates of 10 serial dilutions of genomic DNA were measured by qPCR. Based on the results, an additional measurement was performed on 4 replicates of 10 novel serial dilutions. The measurements included at least one dilution with all replicates positive and one with all replicates negative. A probit analysis was performed using SPSS Statistics 19.0.0 to calculate the DNA concentration that could be measured with $95 \%$ probability.

Efficiency and repeatability were calculated from the log-linear portion of the calibration curve, covering 6 orders of magnitude. Four replicate measurements were obtained from each dilution. Because the variation in Cqs at the lowest template concentration was relatively high, these values were excluded from the calculations.

To investigate the concentration range of internal control B. thuringiensis DNA that could be added to Burkholderia DNA without interfering with the detection of low pathogen concentrations, a dilution series of the internal control was made in the presence of a constant and low concentration of the pathogens. Genomic DNA from Burkholderia mallei or B. pseudomallei (14 and $48 \mathrm{fg} /$ reaction, respectively) was mixed with serial dilutions from genomic DNA from $B$. thuringiensis $\left(1.3 \cdot 10^{1}-\right.$ $1.3 ? \cdot 10^{8} \mathrm{fg} /$ reaction). These DNA mixtures were amplified in triplicate by using the developed qPCR assays and the $\mathrm{Cq}$ values were plotted to investigate possible inhibition.

\section{Results}

Three signature sequences were developed to permit sensitive detection and differentiation of $B$. mallei and B. pseudomallei. ISBma2 transposase is present in multiple copies in both species, thus enabling sensitive detection. Although homologs of this transposase occur in related organisms, a portion of this sequence was identified that is unique for B. mallei and B. pseudomallei. Two unique signature sequences (designated mau and 
Table 2 Panel of organisms used for coverage and specificity analysis

\begin{tabular}{|c|c|c|c|c|c|c|}
\hline \multirow[t]{2}{*}{ Species } & \multirow[t]{2}{*}{ Strain } & \multirow[t]{2}{*}{ Strain details $\mathrm{s}^{\mathrm{a}}$} & \multicolumn{4}{|c|}{ Targets $^{\mathbf{b}}$} \\
\hline & & & BuMC & psu & mau & cry1 \\
\hline $\begin{array}{l}\text { Burkholderia } \\
\text { mallei }\end{array}$ & $\begin{array}{l}\text { NCTC } 10229 \\
\text { NCTC } 10230 \\
\text { NCTC } 10245 \\
\text { NCTC } 10247 \\
\text { NCTC } 10248 \\
\text { NCTC } 10260 \\
\text { NCTC } 120 \\
\text { NCTC } 3708 \\
\text { NCTC } 3709 \\
\text { NCTC } 12938 \text { T }\end{array}$ & $\begin{array}{l}\text { Bird, } 1961 \\
\text { Horse, } 1961 \\
\text { Horse, } 1972 \\
\text { Turkey, } 1960 \\
\text { Clinical isolate, Turkey, } 1950 \\
\text { Clinical isolate, Turkey, } 1949 \\
1920 \\
\text { Mule, India, } 1932 \\
\text { Horse, India, } 1932 \\
\text { Clinical isolate }\end{array}$ & $\begin{array}{l}14,5 \\
14,6 \\
14,1 \\
15,2 \\
12,2 \\
16,2 \\
14,8 \\
14,8 \\
15,0 \\
15,6\end{array}$ & $\begin{array}{l}- \\
- \\
- \\
- \\
- \\
- \\
- \\
- \\
- \\
-\end{array}$ & $\begin{array}{l}19,2 \\
19,3 \\
18,8 \\
19,8 \\
17,4 \\
20,8 \\
19,4 \\
19,4 \\
19,3 \\
20,0\end{array}$ & $\begin{array}{l}- \\
- \\
- \\
- \\
- \\
- \\
- \\
- \\
- \\
-\end{array}$ \\
\hline $\begin{array}{l}\text { Burkholderia } \\
\text { pseudomallei }\end{array}$ & $\begin{array}{l}\text { NCTC } 10274 \\
\text { NCTC } 10276 \\
\text { NCTC } 11642 \\
\text { NCTC } 1688 \\
\text { NCTC } 4845 \\
\text { NCTC } 4846 \\
\text { NCTC } 6700 \\
\text { NCTC } 7383 \\
\text { NCTC } 7431 \\
\text { NCTC } 8016 \\
\text { NCTC } 8707 \\
\text { NCTC } 8708 \\
\text { NCTC } 12939 \text { T } \\
\text { BD08-00100 } \\
\text { BD08-00103 } \\
\text { BD08-00268 } \\
\text { BD10-00211 } \\
\text { BD12-00016 } \\
\text { BD12-00217 }\end{array}$ & $\begin{array}{l}\text { Clinical isolate, Kuala Lumpur, } 1962 \\
\text { Clinical isolate, } 1962 \\
\text { Rat, Malaysia, } 1923 \\
\text { infected laboratory monkey, Singapore,1935 } \\
\text { infected laboratory monkey, Singapore,1935 } \\
\text { Clinical isolate, } 1942 \\
1948 \\
1948 \\
\text { Sheep, Queensland, } 1949 \\
\text { Jordan, } 1946 \\
\text { Jordan, } 1946 \\
\text { Clinical isolate, USA, } 1953 \\
\text { Clinical isolate, Netherlands, } 2008^{c} \\
\text { Clinical isolate, Netherlands, } 2008 \\
\text { Clinical isolate, Netherlands, } 2008 \\
\text { Clinical isolate, Netherlands, } 2010 \\
\text { Clinical isolate, Netherlands, } 2012 \\
\text { Clinical isolate, Netherlands, } 2012\end{array}$ & $\begin{array}{c}16,3 \\
16,5 \\
14,7 \\
16,9 \\
- \\
15,9 \\
15,9 \\
16,0 \\
16,0 \\
17,0 \\
16,6 \\
17,8 \\
- \\
17,0 \\
18,8 \\
16,2 \\
- \\
18,5 \\
19,6\end{array}$ & $\begin{array}{l}18,5 \\
19,0 \\
18,2 \\
19,2 \\
18,8 \\
18,3 \\
18,7 \\
18,7 \\
18,3 \\
18,8 \\
18,8 \\
19,9 \\
18,4 \\
18,3 \\
20,2 \\
19,0 \\
18,6 \\
21,1 \\
22,2\end{array}$ & $\begin{array}{l}- \\
- \\
- \\
- \\
- \\
- \\
- \\
- \\
- \\
- \\
- \\
- \\
- \\
- \\
- \\
- \\
- \\
- \\
-\end{array}$ & $\begin{array}{l}- \\
- \\
- \\
- \\
- \\
- \\
- \\
- \\
- \\
- \\
- \\
- \\
- \\
- \\
- \\
- \\
- \\
- \\
-\end{array}$ \\
\hline $\begin{array}{l}\text { Burkholderia } \\
\text { thailandensis }\end{array}$ & $\begin{array}{l}\text { DSM } 13276 \\
\text { CIP } 106301 \\
\text { CIP } 106302\end{array}$ & $\begin{array}{l}\text { Environmental sample, Thailand } \\
\text { Soil, Thailand, } 1994\end{array}$ & $\begin{array}{l}- \\
- \\
-\end{array}$ & $\begin{array}{l}- \\
- \\
-\end{array}$ & $\begin{array}{l}- \\
- \\
-\end{array}$ & $\begin{array}{l}- \\
- \\
-\end{array}$ \\
\hline Bacillus anthracis & $\begin{array}{l}\text { NCTC } 8234 \\
\text { NCTC } 10340\end{array}$ & $\begin{array}{l}\text { Weybridge, } 1951 \text { (Sterne) } \\
\text { Cow, Edinburgh, } 1963 \text { (Vollum) }\end{array}$ & $\begin{array}{l}- \\
-\end{array}$ & $\begin{array}{l}- \\
-\end{array}$ & $\begin{array}{l}- \\
-\end{array}$ & - \\
\hline $\begin{array}{l}\text { Francisella tularensis } \\
\text { subsp. holarctica (B) }\end{array}$ & BD07-537 & Clinical isolate, Netherlands, 2007 & - & - & - & - \\
\hline Yersinia pestis & $\begin{array}{l}\text { Kenya } 164 \\
\text { Harbin } \\
\text { Madagascar 34-94 }\end{array}$ & $\begin{array}{l}\text { Biovar antiqua, Kenya, }<1952 \\
\text { Biovar mediaevalis, China, }<1948 \\
\text { Biovar orientalis, Madagascar }\end{array}$ & $\begin{array}{l}- \\
- \\
-\end{array}$ & $\begin{array}{l}- \\
- \\
-\end{array}$ & $\begin{array}{l}- \\
- \\
-\end{array}$ & $\begin{array}{l}- \\
- \\
-\end{array}$ \\
\hline Bacillus atrophaeus & ATCC 9372 & & - & - & - & - \\
\hline Bacillus cereus & ATCC 11778 & NCIB Aberdeen, 1962 & - & - & - & - \\
\hline Bacillus coagulans & & Purchased at Raven Labs, USA & - & - & - & - \\
\hline Bacillus megaterium & ATCC 8245 & & - & - & - & - \\
\hline Bacillus pumilus & ATCC 27142 & & - & - & - & - \\
\hline Bacillus subtilis & ATCC 6633 & & - & - & - & - \\
\hline Bacillus thuringiensis & ATCC 29730 & var. galleriae Heimpel & - & - & - & 20,4 \\
\hline Enterobacter cloacae & NCTC 13168 & & - & - & - & - \\
\hline Escherichia coli & ATCC 25922 & Clinical isolate, 1946 & - & - & - & - \\
\hline $\begin{array}{l}\text { Pseudomonas } \\
\text { aeruginosa }\end{array}$ & $\begin{array}{l}\text { ATCC } 15442 \\
\text { ATCC } 27853\end{array}$ & Blood culture, 1969 & - & $\begin{array}{l}- \\
-\end{array}$ & $\begin{array}{l}- \\
-\end{array}$ & $\begin{array}{l}- \\
-\end{array}$ \\
\hline Klebsiella pneumoniae & BD05-258 & Clinical isolate, 2005 & - & - & - & - \\
\hline $\begin{array}{l}\text { Salmonella enterica } \\
\text { subsp. enterica }\end{array}$ & $\begin{array}{l}\text { ATCC } 14028 \\
\text { ATCC } 13076\end{array}$ & $\begin{array}{l}\text { Serovar Typhimurium. } \\
\text { liver, } 1987 \\
\text { Serovar Enteritidis }\end{array}$ & $\begin{array}{l}- \\
- \\
-\end{array}$ & $\begin{array}{l}- \\
- \\
-\end{array}$ & $\begin{array}{l}- \\
- \\
-\end{array}$ & $\begin{array}{l}- \\
- \\
-\end{array}$ \\
\hline Bos taurus & 0469 & Netherlands, 2009 & - & - & - & - \\
\hline
\end{tabular}


Table 2 Panel of organisms used for coverage and specificity analysis (Continued)

\begin{tabular}{|c|c|c|c|c|c|c|}
\hline Chrysops relictus & । & Tissue, Netherlands, 2009 & - & - & - & - \\
\hline \multirow[t]{2}{*}{ Homo sapiens } & Volunteer 8 & Blood, Netherlands, 2009 & - & - & - & - \\
\hline & Volunteer 10 & Blood, Netherlands, 2009 & - & - & - & - \\
\hline Equus ferus caballus & & Tissue, Netherlands, 2010 & - & - & - & - \\
\hline Mus musculus & & Netherlands, 2009 & - & - & - & - \\
\hline Ovis aries & Twello 67 & Slaughterhouse, Netherlands, 2009 & - & - & - & - \\
\hline Rattus norvegicus & 08604 & Netherlands, 2009 & - & - & - & - \\
\hline Rattus rattus & 08402 & Netherlands, 2009 & - & - & - & - \\
\hline Sus scrofa & 566 & Slaughterhouse, Netherlands, 2009 & - & - & - & - \\
\hline
\end{tabular}

psu respectively) differentiate between $B$. mallei and $B$. pseudomallei by their presence or absence. Table 1 shows the oligonucleotides designed for the detection of these signature sequences in the multiplex qPCR assay. This assay uses oligonucleotides to detect the cry 1 gene from Bacillus thuringiensis. Spores from this organism added before DNA extraction thus provide internal checks on the successful recovery and amplification of DNA. The specificity and strain coverage of the assay were validated with the aid of a panel of DNA from $B$. mallei and B. pseudomallei strains, a number of close relatives of these organisms, and several other bacterial and eukaryote strains (Table 2). The assay was able to discriminate correctly between the two species. Clinical samples were obtained from the melioidosis patient from whom B. pseudomallei strain BD10-00211 had been isolated. Samples derived from the liver and spleen tested positive only for signature sequence psu, at Cqs of 37.8 and 34.9 respectively. The enhanced sensitivity of detection of pathogenic Burkholderia with the aid of the multicopy target (BuMC) was demonstrated by the $\mathrm{Cq}$ values for this target, which were clearly lower than those for the single-copy targets (a difference of 4.4 5.2 for B. mallei and 1.3 - 3.5 for B. pseudomallei). The multicopy sequence could not be detected in three of the B. pseudomallei strains (NCTC 4845, NCTC $12939 \mathrm{~T}$ and BD10-00211).

All standard curves had an $\mathrm{R}^{2}$ of $>0.998$ and showed high amplification efficiencies and linearity for the different targets, over at least 6 orders of magnitude (Table 3). Calculation of the limit of detection (LOD) using probit analysis showed high sensitivities of 0.2 and $3.7 \mathrm{fg}$ for B. mallei and B. pseudomallei respectively (based on use of the multicopy target BuMC).

To confirm that the addition of the internal control has no effect on pathogen detection, a dilution series of B. thuringiensis DNA was made in the presence of a constant and very low concentration of Burkholderia DNA. As shown in Figure 1, the detection of all signature sequences of B. mallei and B. pseudomallei was unaffected by the presence of the internal control DNA, even when the latter was present at an excess of $10^{5}: 1$.

\section{Discussion}

Methods for the rapid, specific identification of pathogenic Burkholderia species are important for timely recognition of glanders or melioidosis in patients with general clinical symptoms that could fit various diseases. Both $B$. pseudomallei and B. mallei are intrinsically resistant to many widely-used antibiotics, and susceptibilities differ between the two species $[6,14]$. Identification of and differentiation between the two pathogens could thus help healthcare workers to choose the right antibiotics to treat infected patients.

In regions where these species are endemic, infection with Burkholderia mallei or B. pseudomallei can often be pinpointed by consideration of prevalences and infection risk factors. The presence of the pathogens is less evident in non-endemic areas. Numerous cases of imported melioidosis have been reported [3,6], and are likely to continue to occur as travel and trade increase. Fast diagnostic methods are therefore essential for use in

Table 3 Assay performance

\begin{tabular}{|c|c|c|c|c|c|}
\hline Organism $^{a}$ & Target & Efficiency (\%) & Linear range (fg/reaction) & Repeatability $\left(S D \text { of } C_{q}\right)^{b}$ & $L O D g D N A$ (fg/reaction) $^{c}$ \\
\hline B. mallei & $\begin{array}{l}\text { BuMC } \\
\text { mau }\end{array}$ & $\begin{array}{l}99,0 \\
98,7\end{array}$ & $\begin{array}{l}1.4 \cdot 10^{-1}-1.4 \cdot 10^{6} \\
1.4 \cdot 10^{0}-1.4 \cdot 10^{6}\end{array}$ & $\begin{array}{l}0,072 \\
0,080\end{array}$ & $\begin{array}{l}0.2 \\
4.5\end{array}$ \\
\hline B. pseudomallei & $\begin{array}{c}\text { BuMC } \\
\text { psu }\end{array}$ & $\begin{array}{l}96,6 \\
99,2\end{array}$ & $\begin{array}{l}1 \cdot 10^{0}-1 \cdot 10^{7} \\
1 \cdot 10^{1}-1 \cdot 10^{7}\end{array}$ & $\begin{array}{l}0,085 \\
0,077\end{array}$ & $\begin{array}{l}3,7 \\
57\end{array}$ \\
\hline
\end{tabular}

\footnotetext{
a Organism from which genomic DNA was used for assessment of assay performance.
}

${ }^{b}$ Values represent the average from the standard deviations calculated at 6 different dilutions from 4 replicate Cq measurements.

c Values displayed represent the lowest DNA concentration at which $95 \%$ of the positive samples are detected, as calculated by using probit analysis. 
non-endemic areas, not only to support appropriate patient treatment but also to ensure the safety of laboratory workers culturing unknown organisms for diagnostic purposes. Another scenario in which rapid identification of pathogenic Burkholderia including species distinction is a challenging but essential task is that of deliberate release of these biothreat agents, where appropriate assay methods may be needed e.g. for forensic tracking.

The assay presented in this paper permits sensitive, reliable detection of pathogenic Burkholderia, thanks to the use of qPCR (real-time polymerase chain reaction). It reduces false-negative measurements, thanks to the inclusion of an internal control and the high sensitivity that was achieved.
The idea of adding spores from $B$. thuringiensis as internal controls was based on their properties as highly refractory biological structures. The detection of the B. thuringiensis signature sequence cry1 guarantees successful DNA extraction and amplification from any microorganism in the sample $[11,12]$. The target BuMC was used as a sensitive, specific indicator for the presence of pathogenic Burkholderia strains. The selection of this target based on its presence in multiple copies in all 21 publicly available genomes and its usefulness for sensitive detection was evidenced by the in vitro validation showing lower $\mathrm{Cq}$ values (Table 2). However, the benefit of more sensitive detection did not hold for all strains, since BuMC could not be amplified from three of the B. pseudomallei strains tested (Table 2). The
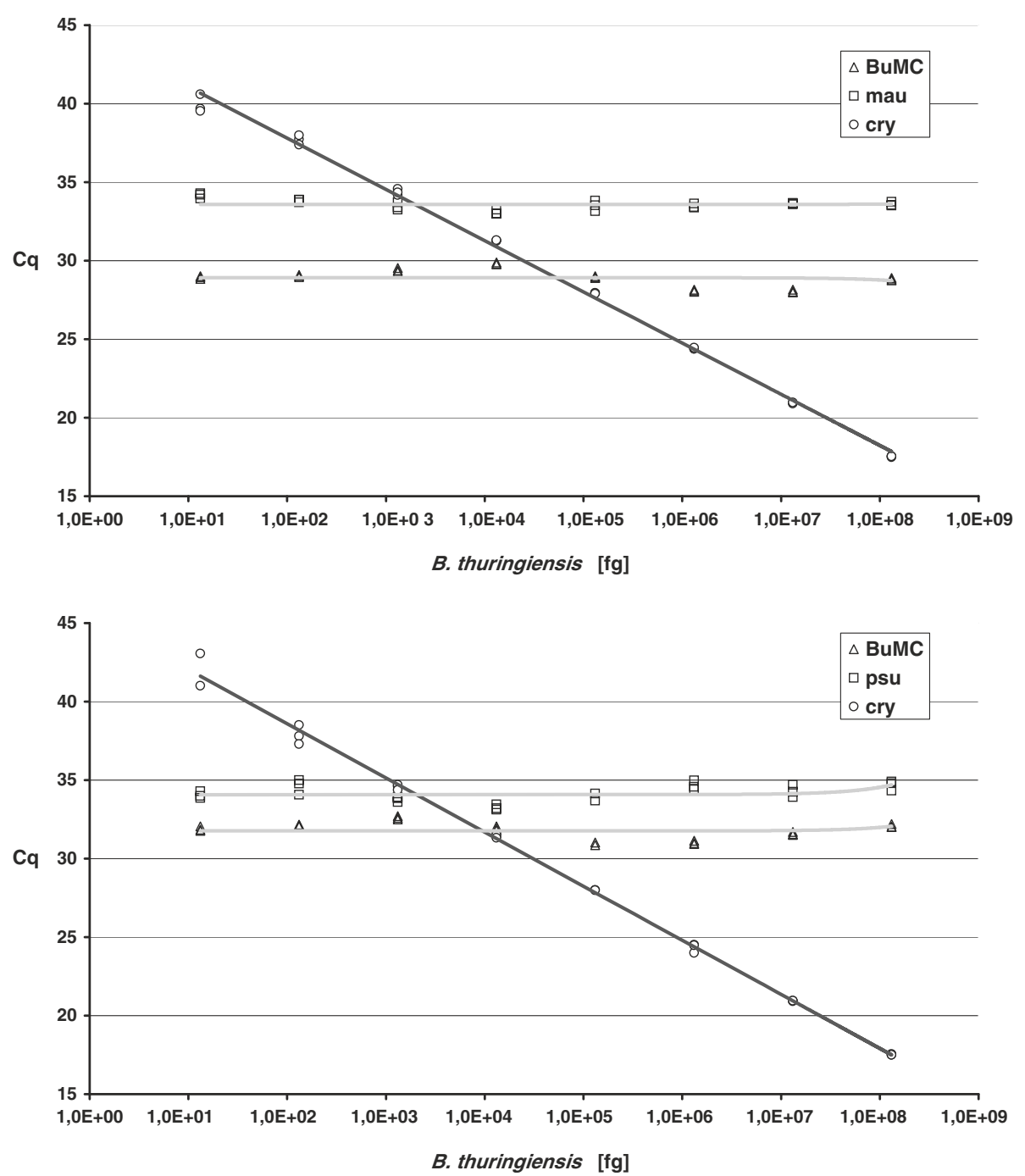

Figure 1 Effect of increasing amounts of internal control on qPCR detection. A concentration range of genomic DNA from $B$. thuringiensis was mixed with a constant and low concentration of $14 \mathrm{fg}$ B. mallei gDNA (A) or 48 B. pseudomallei DNA (B), and measured by using the developed multiplex qPCR. 
absence of this target from the clinical samples is congruent with its absence from strain BD10-00211, which had been isolated from the patient from which the clinical samples were taken. It is possible that the rather diverse species $B$. pseudomallei [9] contains a phylogenetic cluster that has the absence of the targeted ISBma2 transposase gene as a common feature. Further research is required to substantiate this assumption, however.

We did not find any strains that were not detected by the species-specific signature sequences we developed. However, probe design is always limited by the available sequences and strains. Hence, the possibility that some strain exists or could arise which does not possess one of the signature sequences used in this assay cannot be excluded. This is true of any assay, however, and the multiplex qPCR assay described here has the advantage of possessing two signatures for each strain, thus reducing the risk that some strains will escape detection.

The measured linearity and efficiency show that the qPCR assay is very suitable for quantitative measurement. The calculated LODs were very low, particularly when based on multicopy target sequence BuMC. The detection limits of $0.2 \mathrm{fg}$ per reaction for $B$. mallei and $3.7 \mathrm{fg}$ per reaction for B. pseudomallei (Table 3) correspond to approximately 0.03 and 0.5 genomic equivalents respectively. The LODs were lower than or similar to those reported for other assays [6,8,14-19]. However, it is difficult to make a direct comparison between reported LODs due to the differences between the methods used to measure and calculate them, and to measure the DNA concentration of the standards. We used the DNA intercalating dye picogreen for accurate determination of the concentration of double-stranded DNA in our stocks and probit analysis as a basis for robust calculation of the concentration at which the probability of detecting the target is $95 \%$ [11].

The high reliability and sensitivity of the qPCR assay described here make it very useful for screening of samples containing few organisms and potential inhibitors, as is the case in many environmental and clinical samples. It can furthermore be used to supplement other assays, including molecular assays based on other signature sequences, for definitive identification. Burkholderiaceae are highly recombining organisms $[6,9,10,18]$ and emerging novel strains will continue to challenge the coverage and sensitivity of detection assays. This $\mathrm{qPCR}$ assay offers the potential of continuing to meet this challenge effectively in the foreseeable future.

\section{Conclusions}

We designed an assay for rapid and reliable detection of pathogenic Burkholderia spp. The qPCR assay reduces false-negative measurements, due to the inclusion of an internal control and to the high sensitivity that was achieved. Based on a multicopy signature sequence, detection of less than 1 genome equivalent per reaction was possible. Species could be differentiated based on two species-specific signature sequences. The multiplex format limits sample handling, labor and cost per sample. This makes the assay very useful for reliable screening of environmental and clinical samples.

\section{Competing interests}

The authors declare that they have no competing interests.

\section{Authors' contributions}

IJ conceived of and designed the study, performed bioinformatics and probe design, analyzed the data and drafted the manuscript. RAH performed the experimental work and participated in study design and data analysis. $\mathrm{AH}$ performed experimental work. BJVR coordinated the work. All authors read and approved the final manuscript.

\section{Acknowledgements}

The authors would like to thank Frans Reubsaet and Maaike de Vries from $\mathrm{CIB}$, RIVM for sharing bacterial cultures and other genomic materials, and the reviewers for their helpful suggestions concerning improvement of the manuscript.

\section{Author details}

'Laboratory for Zoonoses and Environmental Microbiology, National Institute for Public Health and the Environment (RIVM), Anthonie van

Leeuwenhoeklaan 9, Bilthoven, MA 3721, The Netherlands. ${ }^{2}$ Diagnostic Laboratory for Infectious Diseases and Perinatal Screening, Centre for infectious Disease Control (CIB), National Institute for Public Health and the Environment (RIVM), Bilthoven, the Netherlands.

Received: 2 October 2012 Accepted: 8 February 2013

Published: 14 February 2013

\section{References}

1. Srinivasan A, Kraus CN, DeShazer D, Becker PM, Dick JD, Spacek L, Bartlett $J G$, Byrne WR, Thomas DL: Glanders in a military research microbiologist. N Engl J Med 2001, 345(4):256-258.

2. Wuthiekanun V, Chierakul W, Rattanalertnavee J, Langa S, Sirodom D, Wattanawaitunechai C, Winothai W, White NJ, Day N, Peacock SJ: Serological evidence for increased human exposure to Burkholderia pseudomallei following the tsunami in southern Thailand. J Clin Microbiol 2006, 44(1):239-240.

3. Cuadros J, Gil H, Miguel JD, Marabe G, Gomez-Herruz TA, Lobo B, Marcos R, Anda P: Case report: melioidosis imported from west Africa to Europe. AmJTrop Med Hyg 2011, 85(2):282-284.

4. Brent AJ, Matthews PC, Dance DA, Pitt TL, Handy R: Misdiagnosing melioidosis. Emerg Infect Dis 2007, 13(2):349-351.

5. Weissert C, Dollenmaier G, Rafeiner P, Riehm J, Schultze D: Burkholderia pseudomallei misidentified by automated system. Emerg Infect Dis 2009, 15(11):1799-1801.

6. Bowers JR, Engelthaler DM, Ginther JL, Pearson T, Peacock SJ, Tuanyok A, Wagner DM, Currie BJ, Keim PS: BurkDiff: a real-time PCR allelic discrimination assay for Burkholderia pseudomallei and B. mallei. PLoS One 2010, 5(11):e15413.

7. Schmoock G, Ehricht R, Melzer F, Rassbach A, Scholz HC, Neubauer H, Sachse K, Mota RA, Saqib M, Elschner M: DNA microarray-based detection and identification of Burkholderia mallei, Burkholderia pseudomallei and Burkholderia spp. Mol Cell Probes 2009, 23(3-4):178-187.

8. U'Ren JM, Van Ert MN, Schupp JM, Easterday WR, Simonson TS, Okinaka RT, Pearson T, Keim P: Use of a real-time PCR TaqMan assay for rapid identification and differentiation of Burkholderia pseudomallei and Burkholderia mallei. J Clin Microbiol 2005, 43(11):5771-5774.

9. Holden MT, Titball RW, Peacock SJ, Cerdeno-Tarraga AM, Atkins T, Crossman LC, Pitt T, Churcher C, Mungall K, Bentley SD, et al: Genomic plasticity of the causative agent of melioidosis, 
Burkholderia pseudomallei. Proc Natl Acad Sci USA 2004, 101(39): 14240-14245.

10. Nierman WC, DeShazer D, Kim HS, Tettelin H, Nelson KE, Feldblyum T, Ulrich RL, Ronning CM, Brinkac LM, Daugherty SC, et al: Structural flexibility in the Burkholderia mallei genome. Proc Natl Acad Sci USA 2004, 101(39):14246-14251.

11. Janse I, Bok JM, Hamidjaja RA, Hodemaekers HM, van Rotterdam BJ: Development and comparison of two assay formats for parallel detection of four biothreat pathogens by using suspension microarrays. PLoS One 2012, 7(2):e31958.

12. Janse I, Hamidjaja RA, Bok JM, van Rotterdam BJ: Reliable detection of Bacillus anthracis, Francisella tularensis and Yersinia pestis by using multiplex qPCR including internal controls for nucleic acid extraction and amplification. BMC Microbiol 2010, 10:314

13. Bustin SA, Benes V, Garson JA, Hellemans J, Huggett J, Kubista M, Mueller R, Nolan T, Pfaffl MW, Shipley GL, et al: The MIQE guidelines: minimum information for publication of quantitative real-time PCR experiments. Clin Chem 2009, 55(4):611-622.

14. Thibault FM, Valade E, Vidal DR: Identification and discrimination of Burkholderia pseudomallei, B. mallei, and B. thailandensis by real-time PCR targeting type III secretion system genes. J Clin Microbiol 2004, 42(12):5871-5874.

15. Lee MA, Wang D, Yap EH: Detection and differentiation of Burkholderia pseudomallei, Burkholderia mallei and Burkholderia thailandensis by multiplex PCR. FEMS Immunol Med Microbiol 2005, 43(3):413-417.

16. Suppiah J, Thimma JS, Cheah SH, Vadivelu J: Development and evaluation of polymerase chain reaction assay to detect Burkholderia genus and to differentiate the species in clinical specimens. FEMS Microbiol Lett 2010, 306(1):9-14.

17. Tomaso H, Pitt TL, Landt F, Al Dahouk S, Scholz HC, Reisinger EC, Sprague LD, Rathmann I, Neubauer H: Rapid presumptive identification of Burkholderia pseudomallei with real-time PCR assays using fluorescent hybridization probes. Mol Cell Probes 2005, 19(1):9-20.

18. Tomaso H, Scholz HC, Al Dahouk S, Eickhoff M, Treu TM, Wernery R, Wernery U, Neubauer H: Development of a 5 '-nuclease real-time PCR assay targeting fliP for the rapid identification of Burkholderia mallei in clinical samples. Clin Chem 2006, 52(2):307-310.

19. Ulrich MP, Norwood DA, Christensen DR, Ulrich RL: Using real-time PCR to specifically detect Burkholderia mallei. J Med Microbiol 2006, 55(Pt 5):551-559.

doi:10.1186/1471-2334-13-86

Cite this article as: Janse et al: Multiplex qPCR for reliable detection and differentiation of Burkholderia mallei and Burkholderia pseudomallei. BMC Infectious Diseases 2013 13:86.

\section{Submit your next manuscript to BioMed Central and take full advantage of:}

- Convenient online submission

- Thorough peer review

- No space constraints or color figure charges

- Immediate publication on acceptance

- Inclusion in PubMed, CAS, Scopus and Google Scholar

- Research which is freely available for redistribution

Submit your manuscript at www.biomedcentral.com/submit
C Biomed Central 